\title{
Chemical composition of cool-climate grapes and enological parameters of cool-climate wines
}

Tomasz TARKO*, Aleksandra DudA-CHOdAK, Paweł SATORA, Paweł SROKA, Iga GoJNiczeK

Dep. Ferment. Technol. Techn. Microbiol., Food Technol. Inst. Univ. Agric. Krakow, ul. Balicka 122, 30-149 Krakow, Poland, ttarko@ar.krakow.pl
* Correspondence and reprints

Received 11 December 2012 Accepted 24 May 2013

Fruits, 2014, vol. 69, p. 75-86 (C) 2014 Cirad/EDP Sciences All rights reserved

DOI: 10.1051/fruits/2013103 www.fruits-journal.org

RESUMEN ESPAÑoL, p. 86

\section{Chemical composition of cool-climate grapes and enological parameters of cool-climate wines.}

Abstract - Introduction. Wines produced in cool climate regions may be competitive with wines obtained in traditional wine-producing countries. The aim of this paper was to conduct a quality analysis of the chemical composition of selected varieties of cool-climate grapes and to assess the enological parameters of wines obtained from them. Materials and methods. The chemical composition of 11 varieties of grapes as well as the basic enological parameters, profile of volatile components, and antioxidant and sensory properties of wines obtained from selected varieties were assessed. Results and discussion. The extract content of the assessed varieties of grapes varied within the range of $128.5-218.5 \mathrm{~g} \cdot \mathrm{kg}^{-1}$. The fruit was characterised by similar acidity but significantly heterogeneous antioxidant activity. The basic quality parameters of wines were in accordance with the EU regulations. Antioxidant activity and polyphenol content in red wines were approximately 5-7 times higher than those in white wines. In the sensory assessment the wines obtained high grades. Conclusion. Wines from the cool climate regions fulfil the EU normative requirements and are characterised by original sensory features. They may compete with products from traditional wine-producing countries.

Poland / Vitis vinifera / variety trials / wines / climatic factors / cold zones / antioxidants / phenolic compounds / volatile compounds / organoleptic analysis

\section{Composition chimique des raisins de climat frais et paramètres œnologiques} de leurs vins.

Résumé - Introduction. Les vins produits en régions de climat frais pourraient concurrencer les vins obtenus dans les pays producteurs de vin traditionnel. Le but de cet article a été d'effectuer une analyse de la qualité de la composition chimique de variétés de raisins de climat frais sélectionnées et d'évaluer les paramètres onologiques des vins obtenus à partir d'elles. Matériel et méthodes. La composition chimique de 11 variétés de raisins, ainsi que les paramètres œenologiques de base, le profil des composants volatils et les propriétés antioxydantes et organoleptiques des vins issus des variétés sélectionnées ont été évalués. Résultats et discussion. La teneur en extrait des variétés de raisins évaluées a varié de $(128,5$ à 218,5$) \mathrm{g} \cdot \mathrm{kg}^{-1}$. Les fruits ont présenté une acidité similaire mais leur activité antioxydante a été significativement hétérogène. Les paramètres de qualité de base des vins obtenus ont été en conformité avec la législation européenne. L'activité antioxydante et la teneur en polyphénols des vins rouges ont été environ 5 à 7 fois supérieures à celles des vins blancs. Lors de l'évaluation sensorielle, les vins ont obtenu des notes élevées. Conclusion. Les vins des régions de climat frais remplissent les exigences normatives de l'UE et sont caractérisés par des paramètres sensoriels originaux. Ils peuvent concurrencer les produits en provenance des pays producteurs de vin traditionnels

Pologne / Vitis vinifera / essai de variété / vin / facteur climatique / zone froide / antioxydant / composé phénolique / composé volatil / analyse organoleptique 


\section{Introduction}

Production of grape wines is associated mainly with moderate climate countries with long, hot summers. However, vineyards are also established in countries of less favourable climate. Since 2005, Poland has been included in the coldest zone of grapevine cultivation in Europe (zone A), similar to Germany, Austria and the Czech Republic [1] Wines produced in this climate zone may be competitors to wines obtained in the traditional wine-producing countries. This is mainly possible due to the use in cultivation of new varieties of grapes, called composite hybrids, better adjusted to the cool climate [2]

Climate is undoubtedly one of the most important elements influencing the results of grape cultivation and the quality and type of wine produced [3]. In reference to grape cultivation, most often warm climate and cool climate are distinguished [3]. Cool climate refers to regions where the mean temperature of the month preceding the grape harvest is $15{ }^{\circ} \mathrm{C}$ or less. A characteristic feature of products from the cool climate regions is a significant diversity of quality between individual seasons (vintages). A decrease in temperature below minimum requirements causes the grapes to ripen incompletely. Moreover, compared with the warm climates, grape yields per hectare are lower, so the production costs of wine become higher ${ }^{1}$. Also, the chemical composition of grapes is different; the fruit has a lower content of sugars, and in colder seasons its acidity may be too high. The cool-climate wines are usually perceived as more delicate and refined, and the higher acidity gives freshness to the wines. A characteristic feature of the cool climate regions is also the achievement of better quality of white wines than red wines [3]. Moreover, the cool climate regions are characterised by late and often insufficient fruit ripening. Acidity is increased, which protects the fruit from bacterial attack. However, there is a risk of

\footnotetext{
${ }^{1}$ Report "The Over-supply of Cool Climate Wine Grapes", draft discussion paper for public consultation, Cool Climate Study Steering Committee of the South Australian Wine Industry Council, 2006, http:// www.pir.sa.gov.au/data/assets/pdf file/0018/ 33561/cool_climate_paper_oct06.pdf
}

attack of the grapes by mould of the species Botrytis cinerea due to the higher levels of precipitation in cold climate regions [4]. In the cool climate regions, apart from the increased grape acidity, the $\mathrm{pH}$ of must obtained from them may also be lower than usual. This situation results from the fact that the grapes have a high content of malic acid and tartaric acid [5]. Moreover, the next problem for winemakers may be too low a temperature or frequent rainfall in the period of the planned grape harvest, which can delay the start of fermentation [4]. The most frequent procedure repeatedly necessary in the case of wine production in the cool climate regions is chaptalisation, i.e., adding sugar to the must before fermentation to obtain a normative content of alcohol in the product. Moreover, after alcoholic fermentation very often malolactic fermentation is carried out due to its positive influence on reducing acidity [5].

The selection of an appropriate variety to be cultivated in the cool climate regions is one of the most important issues. The selection can be made on the basis of the resistance of the grape variety to winter frosts, based on the time of fruit ripening and the essential at this time accumulation of temperatures in the vegetation season, or also on the basis of the resistance to unfavourable weather conditions in the flowering and fruit setting periods ${ }^{2}$ [2]. Too late ripening of a given variety excludes its cultivation in a region where autumn ground frost occurs frequently. In the case of resistance to winter frosts, it was found that the cultivation of varieties of the common grapevine with the use of covering for winter allows them to survive and bear fruit despite the temperature falling below $-30{ }^{\circ} \mathrm{C}$. Apart from the above issues, the quickness to start vegetative growth and resistance to the associated spring ground frosts, tolerance of unfavourable weather conditions during the flowering and fruit setting periods and the period of lignification, and also the usable value of the fruits, their quality and usefulness for wine-making, should be taken into account ${ }^{2}$. The last issue

2 Siemaszko J., Cool climate, Winnice Polskie, Poland, 2009, Access. 25 March 2009 (in Polish). http://winnicepolskie.pl/ index.php?option $=$ com_content\&task $=$ blog category\&id $=30$ \&itemid $=79$ 
is the most important criterion because even the best resistance parameters of a given variety do not guarantee obtaining adequate quality wine from it ${ }^{2}$ [2].

In the cool climate regions, cultivation of various varieties of the common grape vine Vitis vinifera is not always successful [2, 6]. Better results are obtained in the case of the so-called composite hybrids (interspecific) which, in the performance characteristics of the fruit, are not much inferior to European grape varieties, and are distinguished by a higher resistance to frost. The hybrids are characterised by high and regular fertility, and also by resistance to diseases [2, 6]. The composite hybrids are cross-breeds of the common grapevine with other Vitis species, mainly American, e.g., Vitis labrusca and Vitis aestivalis (from which originated the so-called American hybrids) and Vitis rupestris and Vitis lincekumii (from which originated the so-called French-American hybrids). These include Marechal Foch, Leon Millot and Aurora [2, 6]. The interspecific hybrids were created in Europe for the first time to prevent attack by phylloxera and other fungal diseases, but wine of satisfactory quality is still produced from them [7]. In recent years, mainly in Germany and Hungary, but also in Poland, hybrid varieties have been implemented that came into existence through the combination of the French-American hybrids with $V$. vinifera varieties, and also V. amurensis (e.g., Rondo, Bianca, Pearl of Zala) [2, 6].

The aim of our study was to perform qualitative analysis of the chemical composition of selected varieties of cool-climate grapes and to assess the enological parameters of wines obtained from them.

\section{Materials and methods}

\subsection{Grapes}

The material was 11 hybrid varieties of grape originating from Podkarpacie, Poland, that had been selected for cultivation in the Polish climate. The grapes used in our experiments originated from the same vineyard and were harvested in one season, so the impact of factors such as cultivation methods, soil and climatic conditions, and insolation can be excluded. Experiments were performed on fruits used for white wine production (Aurora, Bianca, Muskat Odeski, Perła Zali and Prim), for red wines (Alden, Frontenac, Leon Millot, Marechal Foch and Rondo), and for rose wines - the Swenson Red variety. Two grape cultivars were chosen from those mentioned above for wine production during this study.

\subsection{Wine}

The wines analysed in our study were produced in laboratory conditions.

The white wine was made from the Aurora variety of grapes. Fruits were destemmed and crushed, treated with $\mathrm{Na}_{2} \mathrm{~S}_{2} \mathrm{O}_{5}\left(100 \mathrm{mg} \cdot \mathrm{kg}^{-1}\right)$ and pressed with a vertical basket press. The must obtained was sweetened with saccharose to $24 \%$ of extract and inoculated with yeasts at the level of $0.5 \mathrm{~g}$ dry weight per litre of must. Yeasts belonging to Saccharomyces cerevisiae strain Steinberg (originating from the Pure Culture Collection of the Fermentation Technology and Technical Microbiology Department at the University of Agriculture in Krakow, Poland) were used. Then, the must underwent alcohol fermentation (temp. $20^{\circ} \mathrm{C} \pm 2{ }^{\circ} \mathrm{C}, 25$ days). After fermentation, the racking of the young wine was performed and the wine was left for seasoning ( 8 months, $10{ }^{\circ} \mathrm{C} \pm 0.1^{\circ} \mathrm{C}$, thermostatic cabinet).

The red wine was prepared from grapes of the Rondo variety. Fruits, after destemming and crushing, were treated with $\mathrm{Na}_{2} \mathrm{~S}_{2} \mathrm{O}_{5}\left(100 \mathrm{mg} \cdot \mathrm{kg}^{-1}\right)$ and sweetened with saccharose to $24.5 \%$ of extract. The pulp was inoculated with yeasts belonging to Saccharomyces cerevisiae strain Bingen (0.5 g dry weight per litre of pulp, Pure Culture Collection of the Fermentation Technology and Technical Microbiology Department at the University of Agriculture in Krakow, Poland) and the alcoholic fermentation was carried out at $20^{\circ} \mathrm{C} \pm 2{ }^{\circ} \mathrm{C}$. After 8 days the pulp was pressed (vertical basket press) and the fermentation continued for 17 days at $20^{\circ} \mathrm{C} \pm 2{ }^{\circ} \mathrm{C}$. The young wine was racked and left for seasoning 
(8 months, $10{ }^{\circ} \mathrm{C} \pm 0.1{ }^{\circ} \mathrm{C}$, thermostatic cabinet). Each wine type was produced in triplicate.

\subsection{Determination of grape extract content}

Homogenates of $40 \mathrm{~g}$ of grape and $160 \mathrm{~mL}$ of distilled water were prepared (homogeniser Ultra Turrax T 25 basic, IKA ${ }^{\circledR}$, Staufen, Germany; $5 \mathrm{~min}, 22000 \mathrm{rpm}$ ). An amount of $100 \mathrm{~g}$ of homogenate was sampled, boiled for $5 \mathrm{~min}$, and cooled. Then, distilled water was added up to $100 \mathrm{~g}$ and the solution was filtered. The extract content was measured with an Abbe refractometer $\left[\mathrm{g} \cdot \mathrm{kg}^{-1}\right]$. Each sample was analysed with a minimum of three repetitions.

\subsection{Determination of total acidity of grapes}

From the homogenates prepared as above (40 g of grape and $160 \mathrm{~mL}$ of distilled water; homogeniser Ultra Turrax T 25 basic; 5 min; $22000 \mathrm{rpm}$ ), $25 \mathrm{~g}$ was weighed, mixed with $100 \mathrm{~mL}$ of distilled water, and boiled. After cooling, the solution was filtered and a sample of $50 \mathrm{~mL}$ was taken. Then it was titrated with $0.01 \mathrm{M} \mathrm{NaOH}$ solution to $\mathrm{pH}=8.1$. The result was expressed as $\mathrm{g} \cdot \mathrm{kg}^{-1}$ of malic acid. Each sample was analysed with a minimum of three repetitions.

\subsection{Determination of fermenting sugar content in grapes, and glycol and residual sugar in wines}

Ten $g$ of grape sample were triturated in a mortar, resuspended in $50 \mathrm{~mL}$ of water and centrifuged $\left(15 \mathrm{~min}, 2154 \times \mathrm{g}, 20^{\circ} \mathrm{C}\right.$ ). The wines were only centrifuged. The measurements were performed with a liquid chromatograph (HPLC, Dionex, USA). The samples were eluted isocratically at $85^{\circ} \mathrm{C}$ from the ion exchange column (Bio-Rad Aminex HPX 87C, $300 \times 7.8 \mathrm{~mm}$ ) with the mobile phase flow at $0.6 \mathrm{~mL} \cdot \mathrm{min}^{-1}$. An eluent deionised water was used. Before each analysis, samples were dissolved (1:100) and filtered with $0.44-\mu \mathrm{m}$ pore filters. The injection volume was $20 \mu \mathrm{L}$. The chromatography peaks were identified by comparison of particular retention times with external standards. The qualitative and quantitative calculations were performed with Chromeleon 6.80 software (Dionex, USA). Each sample was analysed with a minimum of three repetitions.

\subsection{Titratable acidity, volatile acidity, alcohol concentration and extract contents in wines}

Titratable acidity, volatile acidity, alcohol concentration and extract contents were determined according to the International Organisation of Vine and Wine (OIV) procedures [8]. Each sample was analysed with a minimum of three repetitions.

\subsection{Wine volatile compound analysis (GC-SPME)}

Wine volatile compounds were determined according to Tarko et al. [9]. The qualitative and quantitative identification of volatile substances (1,3-propanodiol, 2-phenylethanol, acetaldehyde, acetoin, acetone, amyl alcohols, butanol, ethyl butylate, diacetyl, hexanol, isobutanol, ethyl isovalerate, methanol, ethyl acetate, pentanol and propanol) was based on the comparison of retention times and peak surface area read from sample and standard chromatograms. Each sample was analysed with a minimum of three repetitions.

\subsection{Antioxidant activity assay}

The antioxidant activity of the grapes and wines was determined by the ABTS radical scavenging assay [9]. Fruits were freezedried, ground and extracted with 80\% methanol $\left(20 \mathrm{~g} \cdot \mathrm{L}^{-1}, 2 \mathrm{~h}\right)$. The extracts were centrifuged $(1745 \times g, 15 \mathrm{~min})$ and the supernatants obtained were used for analysis. Wines were analysed directly after sampling. Antioxidant capacity was calculated with the use of a standard curve $(r=0.999)$ obtained by measuring the absorbance of 


\section{Table I.}

The chemical composition and antioxidant activity of 11 varieties of cool-climate grapevine (Poland).

\begin{tabular}{|c|c|c|c|c|c|c|}
\hline Grape varieties & Extract & $\begin{array}{l}\text { Glucose } \\
\left(\mathrm{g} \cdot \mathrm{kg}^{-1}\right)\end{array}$ & Fructose & $\begin{array}{c}\text { Acidity } \\
\left(\mathrm{g} \text { malic acid } \cdot \mathrm{kg}^{-1}\right)\end{array}$ & $\begin{array}{l}\text { Antioxidant activity } \\
\left(\mathrm{mg} \text { Trolox } \cdot \mathrm{kg}^{-1} \mathrm{dw}\right] \text { ) }\end{array}$ & $\begin{array}{c}\text { Total polyphenol } \\
\text { content } \\
\left(\mathrm{mg} \text { catechin } \cdot \mathrm{kg}^{-1} \mathrm{dw}\right)\end{array}$ \\
\hline Alden & $128.5 \pm 3.5 \mathrm{a}$ & $49.0 \pm 0.2 d$ & $56.5 \pm 0.5 a$ & $9.3 \pm 0.42 a b$ & $55410 \pm 122 a$ & $22410 \pm 262 b$ \\
\hline Aurora & $198.5 \pm 3.5 b c$ & $80.7 \pm 0.5 \mathrm{e}$ & $84.8 \pm 0.7 b$ & $9.8 \pm 0.09 a$ & $64560 \pm 42 b c$ & $22810 \pm 528 b$ \\
\hline Bianca & $194.5 \pm 14.1 \mathrm{bc}$ & $61.9 \pm 3.0 \mathrm{a}$ & $66.7 \pm 3.5 \mathrm{~cd}$ & $7.7 \pm 0.04 c$ & $42290 \pm 52 d$ & $17990 \pm 218 a$ \\
\hline Frontenac & $186.5 \pm 7.1 \mathrm{bd}$ & $67.0 \pm 0.2 b$ & $59.8 \pm 0.7 \mathrm{ae}$ & $17.9 \pm 0.66 \mathrm{~d}$ & $19470 \pm 172 \mathrm{e}$ & $14380 \pm 96 c$ \\
\hline Leon Millot & $218.5 \pm 3.5 c$ & $86.8 \pm 0.5 c$ & $87.7 \pm 0.8 \mathrm{bf}$ & $8.1 \pm 0.28 b c$ & $56530 \pm 314 a$ & $19640 \pm 74 a$ \\
\hline Marechal Foch & $178.5 \pm 7.1 \mathrm{bd}$ & $69.0 \pm 0.5 b$ & $69.7 \pm 1.6 \mathrm{C}$ & $14.3 \pm 0.09$ & $66040 \pm 225 b$ & $27460 \pm 225 d$ \\
\hline Muskat Odeski & $163.5 \pm 10.6 \mathrm{de}$ & $58.4 \pm 0.5 f$ & $63.5 \pm 0.1 \mathrm{de}$ & $7.9 \pm 0.05 b c$ & $71170 \pm 314 f$ & $37270 \pm 482 \mathrm{e}$ \\
\hline Pearl of Zala & $198.5 \pm 3.5 b c$ & $86.9 \pm 0.5 c$ & $90.1 \pm 0.7 f$ & $7.9 \pm 0.52 b c$ & $50420 \pm 83 \mathrm{~g}$ & $17000 \pm 297 f$ \\
\hline Prim & $146.0 \pm 0.0 \mathrm{ae}$ & $63.6 \pm 1.2 \mathrm{a}$ & $66.9 \pm 0.6 \mathrm{~cd}$ & $7.3 \pm 0.57 c$ & $57390 \pm 78 a$ & $18980 \pm 273 a$ \\
\hline Rondo & $178.5 \pm 7.1 \mathrm{bd}$ & $61.8 \pm 1.4 \mathrm{a}$ & $60.5 \pm 2.7 \mathrm{ae}$ & $9.3 \pm 0.14 \mathrm{ab}$ & $141210 \pm 1241 \mathrm{~h}$ & $49190 \pm 567 \mathrm{~g}$ \\
\hline Swenson Red & $171.0 \pm 7.1$ bde & $67.8 \pm 0.3 b$ & $68.9 \pm 0.2 c$ & $11.4 \pm 0.47 \mathrm{e}$ & $59830 \pm 153 a c$ & $19740 \pm 208 a$ \\
\hline
\end{tabular}

synthetic vitamin E (Trolox) solutions and expressed in $\mathrm{mg}$ of Trolox $\mathrm{kg}^{-1}$ of $\mathrm{dw}$ (grapes) or mg of Trolox. $\mathrm{L}^{-1}$ (wine). Each sample was analysed with a minimum of three repetitions.

\subsection{Estimation of total polyphenol content}

Total polyphenol content was determined by the Folin-Ciocalteu method, according to a protocol described previously [9]. The results obtained of total polyphenol content were expressed as $\mathrm{mg}$ of catechin. $\mathrm{L}^{-1}$ (wines) or $\mathrm{mg}$ of catechin. $\mathrm{kg}^{-1}$ of $\mathrm{dw}$ (grapes) based on the standard plot. Each sample was analysed with a minimum of three repetitions.

\subsection{Sensory evaluation}

The sensory assessment of wines was performed using the point method [10]. The panel (20 people) assessed each of the sensory descriptors (taste, aroma, colour and clarity), rating according to a 5-point scale $(1=$ bad to $5=$ very good $)$.

\subsection{Statistical analysis}

The results were shown as an arithmetic mean ( \pm standard deviation). A KołmogorovSmirnov test was applied to examine the normality of distribution. A single-factor analysis of variance test (ANOVA) with a post boc Tukey's test was applied to assess the differences between means.

\section{Results and discussion}

\subsection{Grapes}

Significant diversity of the results within the analysed quality parameters of grapes was observed (table I). The grape extract content varied within the range from (120 to 140) $\mathrm{g} \cdot \mathrm{kg}^{-1}$ (Alden and Prim varieties) to above $190 \mathrm{~g} \cdot \mathrm{kg}^{-1}$ (Leon Millot, Aurora, Bianca and Pearl of Zala). The results obtained for grape extract content depended to a large degree on the quantity of sugar. Among the varieties characterised by a relatively high content of glucose and fructose are the Pearl of Zala, Leon Millot and Aurora varieties (glucose + fructose in total 
165-177 $\left.\mathrm{g} \cdot \mathrm{kg}^{-1}\right)$. Low concentrations of sugars were found in the Alden, Bianca, Frontenac, Odessa Muscat and Prim varieties (glucose + fructose in total 105$\left.129 \mathrm{~g} \cdot \mathrm{kg}^{-1}\right)$. The ratio of glucose to fructose in the case of each of the analysed varieties was close to unity (from 0.88 to 1.12 ). According to Dharmadhikari, this ratio in ripe grapes is close to $1: 1$, while in overripe grapes fructose starts to dominate [11]. However, in terms of technological ripeness this ratio may fluctuate, being mainly dependent on the variety of grape. It is noteworthy that some varieties characterised by relatively high content of extracts (Bianca and Frontenac) contained low concentrations of fermenting sugars (below $130 \mathrm{~g} \cdot \mathrm{kg}^{-1}$ ). One can presume that these varieties contain high quantities of non-sugar extract components. Apart from sugars, the main extract components of fruits include organic acids, nitrogen compounds, pectin, dyes, tannins and mineral salts. However, in berry fruits such as grapes, sugars constitute from 50\% to 67\% of extracts [12]. The extract content and the concentration of fermenting sugars in grapes translate directly into the quality of wines obtained from them. The Pearl of Zala, Leon Millot and Aurora varieties, compared with the other varieties of grapes studied, had a high extract content and concentration of fermenting sugars.

Most of the analysed varieties were characterised by similar acidity $\left(7-8 \mathrm{~g} \cdot \mathrm{kg}^{-1}\right.$ of malic acid). Slightly higher results were obtained for the Aurora, Alden, Rondo and Swenson Red varieties $\left(9.3-11.4 \mathrm{~g} \cdot \mathrm{kg}^{-1}\right.$ of malic acid). Large quantities of acids were found in the grapes of the Frontenac (17.9 $\mathrm{g} \cdot \mathrm{kg}^{-1}$ of malic acid) and Marechal Foch varieties $\left(14.3 \mathrm{~g} \cdot \mathrm{kg}^{-1}\right.$ ). However, these varieties with significantly higher acidity did not show a lower concentration of fermenting sugars compared with the other grapes. So, it should be assumed that this is probably a specific feature. Moreover, according to Myśliwiec, the fruit of the Frontenac variety usually has quite a high content of organic acids, and the wine obtained from this variety is crisply acidulous [13]. Wines produced from the Marechal Foch variety are also characterised by a higher content of organic acids compared with the Leon
Millot variety. According to Wzorek and Pogorzelski, grapes cultivated in cooler regions may show higher acidity, and in parallel, lower sugar content [12]. Tartaric acid and malic acid constitute $69 \%$ to $92 \%$ of all organic acids of grapes, and fruit growing in cool climates contain as a rule higher quantities of malic acid [14].

Since the early 20 th century studies on the chemical composition of grape vines have been carried out in order to explain in detail their biological activity. Natural substances occurring in grapes are first of all polyphenolic compounds (often called bioflavonoids), playing an essential role in the regulation of the metabolism of the human body. The group of polyphenolic compounds includes polyphenolic acids, flavonoids, isoflavonoids, chalcones, anthocyanins, stilbenes, coumarins, lignans and many others [15]. It is thought that high quality, valuable wines are made from grapes rich in phenolic compounds [4]. The source of polyphenols in grapes is first of all seeds and skin, while the pulp and juice are relatively poor in these compounds [16]. On the basis of the experiments conducted it was found that white and red varieties of grapes were characterised by similar antioxidant activity and total polyphenol content. It is noteworthy that the Rondo variety was characterised by the greatest antioxidant activity, $141,210 \mathrm{mg}$ Trolox $\cdot \mathrm{kg}^{-1}$ dry weight, and this is a value significantly diverging from the other results. The antioxidant activity of all studied varieties is relatively high, significantly exceeding the antioxidant capacity of other Polish fruit. Fruit widely used in Poland to make wine are apples. Those fruits are characterised by antioxidant activity of $30,240-40,590 \mathrm{mg}$ Trolox $\cdot \mathrm{kg}^{-1}$ dry weight, depending on variety [17], and contain flavan-3-ols, flavonols and dihydrochalcones [18]. The total polyphenol content of the analysed grapes was closely correlated with the antioxidant activity $(r=$ 0.915). This correlation suggests that first of all, phenolic compounds are responsible for the antioxidant potential of grapes. Antioxidant activity of fruit is also dependent on the content of vitamins, mainly ascorbic acid [19]. Similar to the antioxidant activity, the results concerning the total polyphenol 
content were also clearly highest for the Rondo variety $\left(49,190 \mathrm{mg}\right.$ catechin $\cdot \mathrm{kg}^{-1}$ dry weight).

Based on the characteristics of the chemical composition of the 11 studied varieties of wines and their antioxidant activity, the Aurora variety was selected to make must for white wine, and the Rondo variety for red wine.

\subsection{Wine}

Taking into account our results, white wines (Aurora) compared with red wines (Rondo) had a higher concentration of ethanol (respectively, $14.5 \%$ and $12.5 \%$ by volume), because the grapes of the Aurora variety contained a higher quantity of fermenting sugars (table II). These wines were also characterised by a low content of extracts (26.2-31.3 g. $\mathrm{L}^{-1}$ ) and residual sugar. On the basis of the sugar content the studied wines can be classified as dry wines, in accordance with Commission Regulation no. 1622/2000. Tarko et al. analysed among other things grape wines from the same region (Jasło, Podkarpackie Voivodeship, Poland), but produced in a local winery from grapes picked in 2007 [20]. The results obtained at that time are similar to the current ones, although the currently studied wines were prepared on the laboratory scale. The alcohol content in wines from Podkarpacie reached the level of $10.9 \%$ by volume in the case of white wine (from the Seyval Blanc variety) and $13.4 \%$ by volume in the case of red liqueur wine (from the Leon Millot variety). The total extract content in cool-climate wines was $28 \mathrm{~g} \cdot \mathrm{L}^{-1}$ in the case of white wine (from the Seyval Blanc variety) and $105 \mathrm{~g} \cdot \mathrm{L}^{-1}$ in the case of red liqueur wine (from the Leon Millot variety) [20]. The most important factors controlling the level of ethanol are the sugar content, fermentation temperature and the yeast used. Apart from its physiological significance and effects on the human body, ethanol is an essential factor during stabilisation and ageing processes, and influences the sensory features of wines [5].

The minimum content of glycerol in wines should be approximately $5 \mathrm{~g} \cdot \mathrm{L}^{-1}$, but it can reach even up to $15-20 \mathrm{~g} \cdot \mathrm{L}^{-1}$ [4]. The studied wines contained from (7.6 to 8.6) $\mathrm{g} \cdot \mathrm{L}^{-1}$, which is a comparable quantity to wines from the warm regions. It was reported that Italian wines fermented with Saccharomyces cerevisiae contained approximately $7-8 \mathrm{~g}$ glycerol $\cdot \mathrm{L}^{-1}$, and, with Saccharomycodes ludwigii, 8-9 $\mathrm{g} \cdot \mathrm{L}^{-1}$ [21]. In Spanish wines, Escobal et al. determined the glycerol quantity at the level of 3.9$9.8 \mathrm{~g} \cdot \mathrm{L}^{-1}[22]$.

The general acidity of the two studied wines did not statistically differ and was approximately $6.6-6.7 \mathrm{~g}$ malic acid $\cdot \mathrm{L}^{-1}$. These values are within the EC norm [23] concerning grape wine acidity, i.e., 3.0$9.0 \mathrm{~g} \cdot \mathrm{L}^{-1}$. The volatile acidity of the studied wines was, respectively, $0.29 \mathrm{~g}$ acetic acid $\mathrm{L}^{-1}$ for the white wine Aurora and $0.19 \mathrm{~g}$ acetic acid $\mathrm{L}^{-1}$ for the red wine Rondo (table II). These values are also in accordance with the norm [10].

Similarly, as in the case of grapes, the wines were also analysed for antioxidant activity and total polyphenol concentration (table II). In the case of the red wine made from the Rondo variety the antioxidant activity was approximately 7 times higher than that in the case of the wine from the Aurora variety [respectively, $(8,120$ and 1,100) mg Trolox $\left.\cdot \mathrm{L}^{-1}\right]$. A similar situation was found for total polyphenol concentration [respectively, (2,430 and 460) mg catechin $\left.\cdot \mathrm{L}^{-1}\right)$. The reason for the differences is the process of grape maceration used only when making red wines. Phenol components (anthocyanins, tannins) extracted from grapes (mainly from skin and seeds) give the wine its colour and flavour [4]. The antioxidant activity of wines is closely connected with the content of phenolic compounds $[20,24]$. In the analysed wines the correlation between the total polyphenol content and the antioxidant activity was very high $(r=0.98)$. In recent years great attention has been devoted to resveratrol (a nonflavonoid compound from the stilbene group), which, apart from antibacterial properties, also has strong antioxidant properties. It is thought that the pro-health properties of wines are connected with the presence of this compound in them [5]. Stevanato et al. reported that red wines are 
T. Tarko et al.
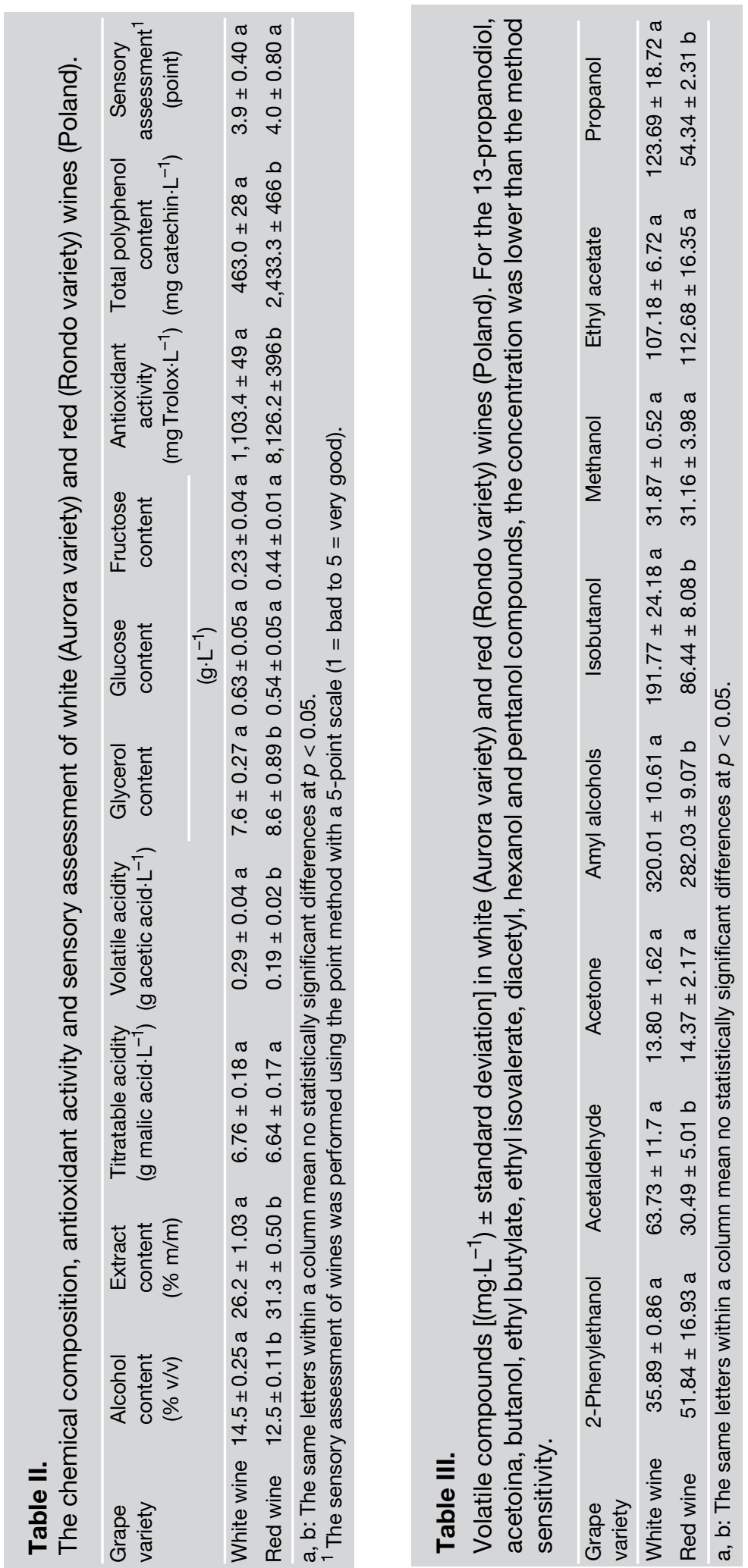
characterised by approximately 12 times higher content of polyphenols [25]. Italian red wines studied by them contained approximately $880-1,100 \mathrm{mg}$ catechin $\cdot \mathrm{L}^{-1}$, and white wines $66-88 \mathrm{mg}$ catechin $\cdot \mathrm{L}^{-1}$. Cliff and Dever, while analysing the chemical composition and sensory profile of Canadian wines from the British Columbia region, found that the total polyphenol content in Chardonnay wines was 150 $333 \mathrm{mg} \cdot \mathrm{L}^{-1}$ (expressed as gallic acid), and wines from the Pinot Noir variety contained 5-9 times more [26]. The aforementioned red and white wines from cooler regions of Podkarpacie contained, respectively, (970 and 180) $\mathrm{mg}$ catechin $\cdot \mathrm{L}^{-1}[20]$. Their antioxidant activity was relatively high: $7,450 \mathrm{mg}$ Trolox $\cdot \mathrm{L}^{-1}$ in red wine from the Leon Millot variety, and $880 \mathrm{mg}$ Trolox $\cdot \mathrm{L}^{-1}$ in white wine from the Seyval Blanc variety.

One of the more important distinguishing sensory features of wine is its colour, on which the general acceptance of the product by the consumer depends, as well as the aroma, being the result of interactions between components derived from grapes and those arising during the vinification process, dependent on such factors as the variety of grapes, technology of wine-making, the environment, the yeast used, etc. [27]. In the general sensory assessment (5point scale) both wines obtained high grades - approximately 4 points (table II). They were characterised by full clarity and intensive characteristic aroma. The red wine obtained a slightly higher grade but the differences compared with the white wine were not statistically significant. The red wine was graded particularly highly due to its deep ruby colour.

\subsection{Profile of volatile components}

The aroma of wine depends to a great extent on the profile of created volatile components, which is why the studied wines were analysed in this scope (table III). Among the higher alcohols the dominant volatile components identified in both wines were isoamyl alcohols. In wines from the Aurora variety these quantities were higher $\left(320 \mathrm{mg} \cdot \mathrm{L}^{-1}\right)$ than in the case of the wine from the Rondo variety $\left(282 \mathrm{mg} \cdot \mathrm{L}^{-1}\right)$. The analysed wines were also characterised by relatively high concentrations of isobutanol and propanol [from (54 to 192$) \mathrm{mg} \cdot \mathrm{L}^{-1}$ ]. In the ester group, only ethyl acetate was identified as significantly influencing the formation of wine aroma. It occurred in the studied wines in quantities of approximately $110 \mathrm{mg} \cdot \mathrm{L}^{-1}$, while slightly greater values were obtained for the red wine from the Rondo variety. In smaller quantities, in the case of both the white and red wine, the following compounds were found: 2-phenylethanol (36-52 $\left.\mathrm{mg} \cdot \mathrm{L}^{-1}\right)$, methanol (31$\left.32 \mathrm{mg} \cdot \mathrm{L}^{-1}\right)$ and acetone $\left(13-14 \mathrm{mg} \cdot \mathrm{L}^{-1}\right)$. Acetaldehyde occurred in the white wine in a quantity almost two times greater than that in the red wine $\left(63.73 \mathrm{mg} \cdot \mathrm{L}^{-1}\right.$ vs. $\left.30.49 \mathrm{mg} \cdot \mathrm{L}^{-1}\right)$. It was found that 1,3 -propanodiol, acetoin, butanol, ethyl butylate, diacetyl, ethyl isovalerate, hexanol and pentanol did not occur in the studied wines or their concentrations were lower than the sensitivity of the applied analytical method.

The main aromatic compounds of wines are higher alcohols classed as secondary metabolites of yeast. They develop during alcoholic fermentation from amino acids (approximately 80\%) and sugars (approximately 20\%). These are, first of all, amyl alcohols (60-80\%), isobutyl alcohol (1520\%) and propanol (4-7\%). Except for 2phenylethanol, which has a rose aroma, higher alcohols are characterised by an unpleasant aroma. Most, e.g., isoamyl alcohols, have a heavy solvent aroma [4]. Higher alcohols are important volatile components of alcoholic beverages and even in small quantities play an important role in forming the sensory profile. According to Vidrich and Hribar the content of fusels in wine should be $80-540 \mathrm{mg} \cdot \mathrm{L}^{-1}$ [28]. Concentration of higher alcohols below $300 \mathrm{mg} \cdot \mathrm{L}^{-1}$ strengthens the desirable wine aroma, whereas these components are seen as a negative factor forming the aroma when their content in wine exceeds $400 \mathrm{mg} \cdot \mathrm{L}^{-1}$.

A significant role in forming the sensory features of wine is played by esters arising from acids and alcohols during and after fermentation of wines. Biosynthesis of esters is dependent mainly on the yeast species, must aeration, temperature and fermentation technique, fruit ripeness, and 
others. Most esters are formed at the beginning of fermentation and their quantity changes only to a small extent during wine ageing [29]. The main representative of this group is ethyl acetate, characterised by a sweet, strong aroma. It usually occurs in wines at a concentration from (50 to 200) $\mathrm{mg} \cdot \mathrm{l}^{-1}[30]$.

\section{Conclusions}

Alden and Prim grapes were clearly characterised by lower content of extracts and fermenting sugars compared with the other varieties. The acidity of most studied varieties of grapes showed similar values. Only two varieties of grapes, Frontenac and Marechal Foch, were characterised by higher acidity, which is probably a specific feature. The white and red varieties of grapes studied were characterised by similar antioxidant activity and total polyphenol content. A high correlation between these parameters was found $(r=0.915)$. It is noteworthy that the Rondo variety was characterised by the greatest antioxidant activity.

Regarding our results, the fundamental enological parameters of wines - the content of ethanol and residual sugar, and general and volatile acidity - were within the Regulation of the European Commission limits. In the group of volatile components, isoamyl alcohol, isobutanol, propanol and ethyl acetate were dominant. Red wines were characterised by over 7 times higher antioxidant activity and over 5 times higher concentration of polyphenols than white wines, which is caused by a different technological process and not by raw material differences. A high correlation between these parameters was found ( $r=0.98)$. Both white and red wines were rated highly by the sensory panel.

\section{References}

[1] Anon., Council Regulation (EC) No 2165/ 2005, Off. J. Eur. Union L 345/1, Bruss., Belg., 2005.
[2] Myśliwiec R., Winorośl i wino, PWRiL, Warszawa, Pol., 2006 (in Polish).

[3] Jackson D., Schuster D., The production of grapes \& wine in cool climates, Dunmore Press Ltd., Wellingt., N.Z., 2001.

[4] Riberéau-Gayon P., Dubourdieu D., Donèche B., Lonvaud A., Handbook of enology, Vol. 1: The microbiology of wine and vinification and Vol. 2: The chemistry of wine stabilization and treatments, John Wiley \& Sons Ltd., Chichester, U.K., 2006.

[5] Jackson R.S., Wine science. Principles and Applications, Elsevier Inc., Lond., U.K., 2008.

[6] Lisek J., Winorośl w uprawie przydomowej i towarowej, Hortpress Sp. z o. o., Warszawa, Pol., 2007 (in Polish).

[7] Pollefeys P., Bousquet J., Molecular genetic diversity of the French-American grapevine hybrids cultivated in North America, Genome 46 (2007) 1037-1048.

[8] Anon., Compendium of international methods of wine and must analysis, Off. Int. Vigne Vin (OIV), Paris, Fr., 2006.

[9] Tarko T., Duda-Chodak A., Sroka P., Satora P., Jurasz E., Polish wines: Characteristics of cool-climate wines, J. Food Compos. Anal. 23 (2010) 463-468.

[10] Anon., Partial and total quality analysis by point method, Polish standard PN-64/A04022, Warsaw, Pol., 1995 (in Polish).

[11] Dharmadhikari M., Composition of grapes, Vineyard Vintage View 9 (1994) 3-8.

[12] Wzorek W., Pogorzelski E., Technologia winiarstwa owocowego i gronowego, Sigma-NOT, Warszawa, Pol. 1998 (in Polish).

[13] Myśliwiec R., Winorośl w ogrodzie, PWRiL, Warszawa, Pol., 2006 (in Polish).

[14] Conde C., Silva P., Fontes N., Dias A.C.P., Tavares R.M., Sousa M.J., Agasse A., Delrot S., Gerós H., Biochemical changes throughout grape berry development and fruit and wine quality, Food 1 (2007) 1-22.

[15] Lutomski J., Mścisz A., Znaczenie prewencyjne związków polifenolowych zawartych w winogronach, Post. Fit. 1 (2003) 6-10 (in Polish).

[16] Waterhouse A.L., The phenolic wine antioxidants, In: Cadenas E., Packer L. (Eds.), Handbook of antioxidants, Marcel Dekker, N.Y., U.S.A., 2002.

[17] Duda-Chodak A., Tarko T., Tuszyński T., Antioxidant activity and polyphenol composition in different apple varieties, in: Rehout 
V. (Ed.), Biotechnology 2006, Plant Biotechnology, Sci. Pedagog. Publ., Česke Budějovice, Czech Rep., 2006.

[18] Jakopic J., Slatnar A., Stampar F., Veberic R., Simoncic A., Analysis of selected primary metabolites and phenolic profile of 'Golden Delicious' apples from four production systems, Fruits 67 (2012) 377-386.

[19] Gordon A., Friedrich M., Martins da Matta V., Herbster Moura C.F., Marx F., Changes in phenolic composition, ascorbic acid and antioxidant capacity in cashew apple (Anacardium occidentale L.) during ripening, Fruits 67 (2012) 267-276.

[20] Tarko T., Duda-Chodak A., Sroka P., Satora P., Jurasz E., Physicochemical and antioxidant properties of selected polish grape and fruit wines, Acta Sci. Pol. Tech. Aliment. 7 (2008) 35-45.

[21] Brandolini V., Salzano G., Maietti A., Caruso M., Tedeschi P., Mazzotta D., Romano P., Automated multiple development method for determination of glycerol produced by wine yeasts, World J. Microbiol. Biotechnol. 18 (2002) 481-485.

[22] Escobal A., Iriondo C., Laborra C., Elejalde E., Gonzalez I., Determination of acids and volatile compounds in red Txakoli wine by high-performance liquid chromatography and gas chromatography, J. Chromatogr. 823 (1998) 349-354.

[23] Anon., Commission Regulation (EC) No 1622/2000, Off. J. Eur. Union, L 194, Bruss., Belg., 2000.
[24] Fogliano V., Verde V., Randazzo G., Ritieni A., Method for measuring antioxidant activity and its application to monitoring the antioxidant capacity of wines, J. Agric. Food Chem. 47 (1999) 1035-1040.

[25] Stevanato R., Fabris S., Momo F., New enzymatic method for the determination of total phenolic content in tea and wine, J. Agric. Food Chem. 52 (2004) 6287-6293.

[26] Cliff M.A., Dever M.C., Sensory and compositional profiles of British Columbia Chardonnay and Pinot Noir wines, Food Res. Int. 29 (1996) 317-323.

[27] Gómez-Míguez M.J., Gómez-Míguez M., Vicario M.I., Heredia F.J., Assessment of colour and aroma in white wines vinifications: Effects of grape maturity and soil type, J. Food Eng. 79 (2007) 758-764.

[28] Vidrich R., Hribar J., Synthesis of higher alcohols during cider processing, Food Chem. 67 (1999) 287-294.

[29] De la Roza C., Laca A., Garcia L.A., Diaz M., Ethanol and ethyl acetate production during the cider fermentation from laboratory to industrial scale, Process Biochem. 38 (2003) 1451-1456.

[30] Rocha S.M., Rodrigues F., Coutinho P., Delgadillo I., Coimbra M.A., Volatile composition of Baga red wine, Assessment of the identification of the would-be impact odorants, Anal. Chim. Acta 513 (2004) 257-262. 


\section{Composición química de las uvas de clima fresco y parámetros enológicos de sus vinos.}

Resumen - Introducción. Los vinos producidos en regiones de clima fresco podrían competir con los vinos procedentes de los países productores de vino tradicional. Este artículo pretendió realizar un análisis cualitativo de la composición química de variedades seleccionadas de uvas de clima fresco y evaluar los parámetros enológicos de los vinos obtenidos a partir de dichas variedades. Material y métodos. Se evaluó la composición química de 11 variedades de uvas, así como los parámetros enológicos básicos, el perfil de los compuestos volátiles y las propiedades antioxidantes y organolépticas de los vinos resultantes de las variedades seleccionadas. Resultados y discusión. La cantidad de extracto de las variedades de uvas evaluadas varió entre $(128,5$ y 218,5$) \mathrm{g} \cdot \mathrm{kg}^{-1}$. Los frutos presentaron una acidez similar, pero su actividad antioxidante fue significativamente heterogénea. Los parámetros cualitativos básicos de los vinos obtenidos fueron conformes a la legislación europea. La actividad antioxidante y el contenido de polifenoles de los vinos tintos fueron aproximadamente de 5 a 7 veces superiores a los de los vinos blancos. En cuanto a la evaluación sensorial, los vinos obtuvieron altas calificaciones. Conclusión. Los vinos de las regiones de clima fresco cumplen con las exigencias normativas de la UE y se caracterizan por parámetros sensoriales originales. Pueden competir con los productos procedentes de países tradicionales, productores de vino.

Polonia / Vitis vinifera / ensayos de variedades / vinos / factores climáticos / zona fría / antioxidantes / compuestos fenólicos / compuesto volátil / análisis organoléptico 